\title{
Antioxidant activities and lutein content of 11 marigold cultivars (Tagetes spp.) grown in Thailand
}

\author{
Pajaree INGKASUPART ${ }^{1}$, Benya MANOCHAI², Woo Tae SONG ${ }^{1}$, Jeong Hwa HONG ${ }^{1 \star}$
}

\begin{abstract}
Antioxidant activities and total phenolic content (TPC) were analyzed in ethanol extracts of 11 marigold cultivars grown in Thailand. Antioxidant activity assays performed in this study were the 2,2'-azino-bis(3-ethylbenzothiazoline-6-sulphonic acid) (ABTS) radical cation scavenging activity, ferric ion reducing antioxidant power (FRAP), 2,2-diphenyl-1-picrylhydrazyl (DPPH) radical scavenging activity, oxygen radical absorbance activity (ORAC), and superoxide anion radical scavenging activity (SRSA) assays. 'Optiva Orange' showed the best activity in the ORAC assay and in \% SRSA, as well as the highest content of lutein $(20.59 \mathrm{mg})$, gallic acid $(25.77 \mathrm{mg})$, and quercetin $(12.61 \mathrm{mg})$ per gram dry marigold petal among the 11 cultivars. Furthermore, 'Optiva Orange' showed the highest lutein yield per plant, as compared to other cultivars. In contrast, 'Rodeo Gold' showed the highest activity by ABTS testing ( $0.92 \mathrm{mmol}$ of trolox/g dry sample), as well as an $89.90 \%$ inhibition of DPPH. Lutein content showed a positive correlation with TPC and all antioxidant activity assays. In conclusion, 'Optiva Orange' and 'Rodeo Gold' could be utilized as a good lutein source for functional food products and cosmetics.
\end{abstract}

Keywords: marigold cultivars; antioxidant activity; phytochemical.

Practical Application: Two marigold cultivars grown in Thailand showed high antioxidant activity among 11 cultivars tested.

\section{Introduction}

Marigold (Tagetes spp.) is an ornamental plant belonging to the Asteraceae family, numerous species of which are found all over the world (Piccaglia et al., 1998). A number of marigold species are reported to possess therapeutic usage in various ailments, such as skin complaints, wounds and burns, conjunctivitis and poor eyesight, menstrual irregularities, varicose veins, hemorrhoids, duodenal ulcers, etc. (Wichtl \& Bisset, 1994; Ćetković et al., 2004). The two major classes of pigments present in the Tagetes spp. are the flavonoids and carotenoids (Vasudevan et al., 1997). The lutein ester carotenoids, in particular, have been identified as the principal pigment components in marigold flowers (Gong et al., 2012). Flavonoids are a class of secondary plant metabolites that are thought to exert several effects beneficial to human health through their antioxidant and chelating properties (Heim et al., 2002; Č́íz et al., 2010). These are commonly found in both edible and non-edible plants, and have been reported to exert multiple biological effects, including antioxidant activity (Kähkönen et al., 1999).

Various tests and methods have been developed and adapted to specifically assess the presence and activity of antioxidants in foodstuffs, nutraceuticals, dietary supplements, and biological fluids (Huang et al., 2005; Ma et al., 2011). As no single assay can accurately reflect the activities of all antioxidants in a mixed or complex system, a combination of different antioxidant assays must be performed in order to outline a complete antioxidant activity profile (Ma et al., 2011).
The uses of lutein extracts in the formulation of nutritional supplements for the prevention of age-related macular degeneration (AMD) have become increasingly popular over the past few years (Kijlstra et al., 2012). Synthetic methods have been developed for the production of lutein; however, the cost of production cannot compete with that of lutein isolation from marigold extracts (Fernández-Sevilla et al., 2010). Many studies have reported on the increase in the use of marigold extracts in functional food stuffs, cosmetics, and the pharmaceutical industry (Li et al., 2007; Hojnik et al., 2008). To date, marigold petals have also been one of the main industrial sources for lutein production.

Only a few reports have been published on the Thai marigold extract, and its lutein content and antioxidant activity. This study is directed towards determining the best marigold cultivars for commercial applications, with respect to lutein yield and antioxidant activity.

\section{Materials and methods}

\subsection{Plant material and chemicals}

All marigold cultivars were obtained from the AFM Flower Seeds Company (Chiangmai, Thailand) except for the 'Daonoi' breed, which was supplied by the East-West Seed Company (Nonthaburi, Thailand), and grown at the KU farm located in the Kasetsart University campus, Bangkok, Thailand. The completely randomized experimental design (CRD) was used on the 11 cultivars with 10 replicates. The plants were grown in 
an 8 inch pot $(2.6 \mathrm{~L}$ ) of mixed soil media (34.01\% organic matter $(\mathrm{w} / \mathrm{w}), 0.22 \% \mathrm{P}_{2} \mathrm{O}_{5}, 0.67 \% \mathrm{~K}_{2} \mathrm{O}, \mathrm{pH} 6.33, \mathrm{EC}=1.4 \mathrm{dSm}^{-1}, 0.80 \%$ $\mathrm{CaO}, 0.20 \% \mathrm{MgO}$, and $0.13 \% \mathrm{~S}$ ). One gram of NPK (nitrogenphosphorus-potassium) fertilizer was applied to these pots every week from the time the saplings were 21 days old until the time of harvest. Flowers were harvested 13 weeks after sowing, and dried at $60^{\circ} \mathrm{C}$ for $48 \mathrm{~h}$. The dried marigold petals were stored in plastic bags and protected from exposure to light, for further study. All chemicals used were of analytical grade and purchased from Sigma-Aldrich (St. Louis, MO, USA.). Lutein (LT), gallic acid (GA), quercetin (QT) standard, and all solvents used were of HPLC grade.

\subsection{Extraction of marigold petals}

Dried marigold petals from 11 cultivars were extracted with $95 \%$ ethanol by continuous shaking at $120 \mathrm{rpm}$ at $25^{\circ} \mathrm{C}$ for $24 \mathrm{~h}$. The sample was then filtered through a $0.45 \mu \mathrm{m}$ membrane, and the filtrate stored at $4^{\circ} \mathrm{C}$ in a refrigerator in the absence of light.

\subsection{Determination of total phenolic content (TPC)}

The total phenolic content in the marigold extracts was quantified using the Folin-Ciocalteu method described by Al-Duais et al. (2009). Twenty $\mu \mathrm{L}$ aliquots of marigold petal extract (MPE) were mixed with $100 \mu \mathrm{L}$ Folin-Ciocalteu reagent (1:10 diluted in distilled water). The mixture was incubated for $2 \mathrm{~min}$, followed by addition of $75 \mu \mathrm{L}$ of $75 \mathrm{~g} / \mathrm{L} \mathrm{NaCO}_{3}$ solution. This reaction mixture was incubated in the dark at room temperature for $2 \mathrm{~h}$, and the absorbance measured at $760 \mathrm{~nm}$. The total phenolic content was expressed as mg of GA/g dry marigold petal.

\subsection{Assays for the estimation of antioxidant activity}

\section{ABTS radical cation scavenging activity assay}

The ABTS assay was carried out as per the procedures detailed by Sharma et al. (2008), with minor modifications. An $\mathrm{ABTS}^{++}$working solution was prepared daily by diluting the $\mathrm{ABTS}^{++}$stock solution with ethanol to get an absorbance of $0.70 \pm 0.02$ at wavelength $734 \mathrm{~nm}$. Briefly, $20 \mu \mathrm{L}$ aliquots of the MPE were mixed with $200 \mu \mathrm{L} \mathrm{ABTS}{ }^{*+}$ working solution. The mixture was incubated at $25^{\circ} \mathrm{C}$ in darkness for $4 \mathrm{~min}$, and the absorbance measured. The MPE activity was expressed as mmol of trolox/g dry marigold petal.

\section{Ferric ion reducing antioxidant power (FRAP) assay}

FRAP assay was carried out according to the methods detailed by Benzie \& Strain (1996) and Al-Duais et al. (2009). Twenty $\mu \mathrm{L}$ aliquots of the MPE were mixed with $200 \mu \mathrm{L}$ of freshly prepared FRAP working reagent. The FRAP working reagent consisted of $25 \mathrm{~mL} 300 \mathrm{mM}$ acetate buffer ( $\mathrm{pH} 3.6$ ) and $2.5 \mathrm{~mL} 20 \mathrm{mM}$ $\mathrm{FeCl}_{3} \cdot 6 \mathrm{H}_{2} \mathrm{O}$. In addition, $2.5 \mathrm{~mL}$ of $10 \mathrm{mM}$ 2,4,6-Tris (2-pyridyl)S-triazina dissolved in $40 \mathrm{mM}$ HCL was added, and the final mixture incubated at $25^{\circ} \mathrm{C}$ in darkness for $8 \mathrm{~min}$. Following this, the absorbance was measured at $593 \mathrm{~nm}$. The activities were expressed as mmol of trolox/g dry marigold petal.

\section{$D P P H$ radical scavenging activity assay}

The reaction mixtures contained $200 \mu \mathrm{L}$ of $150 \mu \mathrm{M}$ DPPH (2,2-diphenyl-1-picrylhydrazyl) in $95 \%$ ethanol, and $22 \mu \mathrm{L}$ of diluted MPE. The mixture was incubated in the dark at room temperature for $30 \mathrm{~min}$, and the absorbance recorded at $517 \mathrm{~nm}$ as detailed in a previous study (Fukumoto \& Mazza, 2000). The percentage scavenging activity of the DPPH radicals was calculated as follows: $\left[\left(\mathrm{Abs}_{\text {blank }}-\mathrm{Abs}\right.\right.$ sample $\left.) / \mathrm{Abs}_{\text {blank }}\right] \times 100$, at MPE concentration of $20 \mathrm{mg} / \mathrm{mL}$.

\section{Oxygen radical absorbance activity (ORAC) assay}

Twenty $\mu \mathrm{L}$ aliquots of MPE and $120 \mu \mathrm{L}$ of fluorescein (final concentration, $70 \mathrm{nM}$ ) were mixed in a 96-well microplate, and pre-incubated for $15 \mathrm{~min}$ at $37^{\circ} \mathrm{C}$ in the Synergy HT Multi-Detection microplate reader (BioTek, Winooski, VT, USA). The reaction was initiated by the addition of $60 \mu \mathrm{L} 2,2^{\prime}$-Azobis (2-methylpropionamidine) dihydrochloride (AAPH; $12 \mathrm{mM}$ final concentration). The fluorescence values were kinetically recorded every minute for $120 \mathrm{~min}$, using a $485 \mathrm{~nm}$ excitation and a $528 \mathrm{~nm}$ emission filter. The activity of the MPE was expressed as mmol of trolox/g dry marigold petal as described in a previous study (Dávalos et al., 2005). The net area under the curve (AUC) of the samples was calculated by subtracting the AUC of the blank.

\section{Superoxide anion radical scavenging activity (SRSA) assay}

The scavenging activity was measured using the method detailed by Lin \& Chou (2004). The reagent mixture containing $50 \mu \mathrm{L}$ aliquot of MPE, $50 \mu \mathrm{L}$ of $300 \mu \mathrm{M}$ nitrotetrazolium blue chloride, $50 \mu \mathrm{L}$ of $936 \mu \mathrm{M} \mathrm{NADH}$, and $50 \mu \mathrm{L}$ of $120 \mu \mathrm{M}$ phenazine methosulfate, was incubated at room temperature for $5 \mathrm{~min}$. Subsequently, the absorbance was measured at $560 \mathrm{~nm}$ against that of the blank sample. The percentage of superoxide anion radical scavenging activity was then calculated using the following equation: \% Scavenging effect $=\left[\left(\mathrm{Abs}_{\text {blank }}-\mathrm{Abs}_{\text {sample }}\right) / \mathrm{Abs}_{\text {blank }}\right]$ $\times 100$, at MPE concentration of $0.33 \mathrm{mg} / \mathrm{mL}$.

\subsection{Analysis of lutein content}

Marigold dry petals were mixed with an extractant (hexane:acetone:absolute ethanol:toluene; 10:7:6:7) at ratio of 1:60. The MPE were saponified and lutein was extracted according to the method of Bhattacharyya et al. (2010). Lutein quantification was achieved by the method detailed by Piccaglia et al. (1998). Briefly, $20 \mu \mathrm{L}$ of the diluted saponified MPE were injected into the HPLC column, a Gemini C18 reversed-phase column (250 mm $\times 4.6 \mathrm{~mm}, 5 \mu \mathrm{m}$; Phenomenex, Torrance, CA, USA) mounted on an Ultimate 3000 HPLC system (Dionex Corporation, Sunnyvale, CA, USA). The peaks were identified by comparing the retention time and spectrum to that of the lutein standard. The LT content was expressed as $\mathrm{mg}$ of LT/g dry marigold petal.

\subsection{Analysis of gallic acid and quercetin content}

The marigold dry petals were saponified as the same process above in 2.5. Twenty $\mu \mathrm{L}$ of diluted saponified MPE were injected into the same HPLC system that used for lutein analysis. The GA 
and QT contents were determined using the method described by Kumar et al. (2008). The peak was identified based on a comparison of the retention time and spectrum values with those of the GA and QT standard. GA content was expressed as mg of GA/g dry marigold petal and the QT content was expressed as mg of QT/g dry marigold petal.

\subsection{Statistical analysis}

The marigold extracts of each cultivar were analyzed in triplicate, and mean values were reported. Differences between the samples were evaluated by the analysis of variance (ANOVA) and Duncan's multiple-range test, using the SPSS program (version 13; IBM, Armonk, NY, USA). Linear correlations were evaluated by the Pearson method.

\section{Results and discussion}

\subsection{Antioxidant activity of the electron transfer reaction mode}

The results of the ABTS, FRAP, and DPPH assays of marigold petal extracts from 11 cultivars are presented in Table 1. In case of ABTS, the antioxidant activity ranged between 0.44 and $0.92 \mathrm{mmol}$ of trolox/g dry marigold petal. 'Rodeo Gold' showed the highest ABTS value among all the cultivars tested, followed by 'Optiva Orange' and 'Sovereign Gold' breeds, whereas the antioxidant activities for 'Columbus Orange' and 'Lunar Orange' were the lowest. The FRAP values varied between 0.31 and $0.62 \mathrm{mmol}$ of trolox/g dry marigold petal. 'Rodeo Gold' and 'Optiva Orange' displayed the highest FRAP values of 0.62 and $0.61 \mathrm{mmol}$ of trolox/g dry marigold petal, respectively. The lowest FRAP value was found in the 'Columbus Orange' cultivar. For the DPPH assay, free radical scavenging activity was expressed as \% inhibition, and ranged between 46.6 and 89.9. 'Rodeo Gold' and 'Optiva Orange' showed the highest \% inhibition values, followed by 'Rodeo Orange, 'Barbuda Gold', and 'Sovereign Gold' cultivars, respectively. In contrast, the 'Lunar Orange' cultivar showed the lowest \% inhibition value at $46.6 \%$. MPE from 'Rodeo gold' and 'Optiva Orange' cultivars showed remarkably high antioxidant activities in terms of ABRS, FRAP, and DPPH values.

\subsection{Antioxidant activities determined by fluorescent probe and superoxide radicals}

The ORAC assay is based on the principle of free radical damage to a fluorescent probe, such as fluorescein (Ou et al., 2001). This assay is particularly useful for samples containing multiple ingredients, which display complex reaction kinetics (Karadag et al., 2009). The results of the ORAC assay conducted on marigold petal extracts are listed in Table 1. The antioxidant activities of the assayed samples ranged between 1.64 and $1.93 \mathrm{mmol}$ of trolox/g dry marigold petal. 'Optiva Orange' showed the highest ORAC value, followed by 'Rodeo Gold' and 'Sovereign Gold' cultivars. In this assay, the 'Columbus Orange,' 'Discovery Orange, 'Lunar Orange', and 'Daonoi' cultivars showed the lowest antioxidant potential.

Superoxide radicals were generated in the PMS (phenazinemethosulfate)-NADH system by the oxidation of NADH. These were analyzed by NBT (nitro-blue tetrazolium) reduction, which was measured as a decrease in color following addition of the antioxidant (Sokolova et al., 2011). The percentage scavenging activity, as determined by the SRSA assay varied from 77.13 to $115.00 \%$ (Table 1 ). The highest $\%$ scavenging activity was observed in 'Optiva Orange', followed by 'Rodeo Gold' and 'Rodeo Orange.' 'Daonoi' showed the lowest \% scavenging activity when compared to those shown by other marigold cultivars. A suitable sample dilution was to be determined for the SRSA assay, as the sample concentration was important for the interpretation of assay results (Sokolova et al., 2011). In the case of our assay, the proper concentration was determined to be $0.33 \mathrm{mg}$ of dry sample/mL.

\subsection{Phytochemical content in different marigold cultivars}

The major phytochemical antioxidants in marigold petal extracts were reported to be phenolics and carotenoids. Phenolics in the extract mainly constituted gallic acid and quercetin (Kaisoon et al., 2011), whereas lutein is a major carotenoid present in marigold petals (Rivas, 1989).

Total phenolic content (TPC) for all tested marigold cultivars is listed in Table 1. The TPC values ranged from 37.25 to $79.04 \mathrm{mg}$ of GA/g dry marigold petal. 'Rodeo Gold' and 'Optiva Orange'

Table 1. Total phenolic content and antioxidant activity values of 11 marigold cultivars using different assays.

\begin{tabular}{lcccccc}
\hline \multicolumn{1}{c}{ Cultivar name } & TPC & ABTS & FRAP & DPPH & ORAC & SRSA \\
\hline 'Discovery Orange' & $49.48^{\mathrm{d}}$ & $0.71^{\mathrm{c}}$ & $0.39^{\mathrm{e}}$ & $76.16^{\mathrm{d}}$ & $1.66^{\mathrm{e}}$ & $91.54^{\mathrm{cd}}$ \\
'Summer Sun Orange' & $47.56^{\mathrm{e}}$ & $0.61^{\mathrm{d}}$ & $0.33^{\mathrm{f}}$ & $54.06^{\mathrm{f}}$ & $1.76^{\mathrm{d}}$ & $88.20^{\mathrm{d}}$ \\
'Columbus Orange' & $37.38^{\mathrm{g}}$ & $0.44^{\mathrm{f}}$ & $0.25^{\mathrm{h}}$ & $50.82^{\mathrm{g}}$ & $1.64^{\mathrm{e}}$ & $84.56^{\mathrm{de}}$ \\
'Rodeo Gold' & $79.04^{\mathrm{a}}$ & $0.92^{\mathrm{a}}$ & $0.62^{\mathrm{a}}$ & $89.90^{\mathrm{a}}$ & $1.92^{\mathrm{ab}}$ & $109.21^{\mathrm{ab}}$ \\
'Rodeo Orange' & $72.13^{\mathrm{b}}$ & $0.71^{\mathrm{c}}$ & $0.56^{\mathrm{b}}$ & $87.05^{\mathrm{ab}}$ & $1.85^{\mathrm{c}}$ & $107.57^{\mathrm{b}}$ \\
'Lunar Orange' & $37.25^{\mathrm{g}}$ & $0.44^{\mathrm{f}}$ & $0.26^{\mathrm{h}}$ & $46.60^{\mathrm{h}}$ & $1.68^{\mathrm{e}}$ & $80.70^{\mathrm{ef}}$ \\
'Barbuda Gold' & $64.54^{\mathrm{c}}$ & $0.72^{\mathrm{c}}$ & $0.48^{\mathrm{d}}$ & $86.21^{\mathrm{b}}$ & $1.81^{\mathrm{cd}}$ & $109.80^{\mathrm{c}}$ \\
'Jamica Orange' & $63.12^{\mathrm{c}}$ & $0.69^{\mathrm{c}}$ & $0.49^{\mathrm{c}}$ & $80.89^{\mathrm{c}}$ & $1.84^{\mathrm{c}}$ & $86.19^{\mathrm{de}}$ \\
'Optiva Orange' & $78.18^{\mathrm{a}}$ & $0.80^{\mathrm{b}}$ & $0.61^{\mathrm{a}}$ & $89.43^{\mathrm{a}}$ & $1.93^{\mathrm{a}}$ & $115.00^{\mathrm{a}}$ \\
'Sovereign Gold' & $73.12^{\mathrm{b}}$ & $0.78^{\mathrm{b}}$ & $0.57^{\mathrm{b}}$ & $86.17^{\mathrm{b}}$ & $1.87^{\mathrm{b}}$ & $96.44^{\mathrm{c}}$ \\
'Daonoi' & $43.55^{\mathrm{f}}$ & $0.49^{\mathrm{e}}$ & $0.31^{\mathrm{g}}$ & $57.77^{\mathrm{e}}$ & $1.68^{\mathrm{e}}$ & $77.13^{\mathrm{f}}$ \\
\hline
\end{tabular}

TPC assay expressed as mg of GA/g. ABTS, FRAP, and ORAC assay expressed as mmol of trolox/g. DPPH assay expressed as \% inhibition. SRSA assay expressed as \% scavenging activity. Significantly different at $95 \%$ level of confidence based on Duncan's multiple-range test. Means denoted with different letters within the same column were observed to differ significantly $(\mathrm{n}=3)$. 
displayed the highest total phenolic contents of 79.04 and $78.18 \mathrm{mg} \mathrm{GA} / \mathrm{g}$ dry marigold petal, respectively, followed by 'Sovereign Gold' and 'Rodeo Orange.' 'Columbus Orange' and 'Lunar Orange' showed the lowest total phenolic content. Li et al. (2007) reported that TPC and antioxidant activity of the ethanol extracts of 11 cultivars of Chinese marigold, which showed higher TPC and ABTS values than those observed in this study. The low activity obtained in our study, may be due to the effect of prolonged drying time. The antioxidant activity of red grape pomace peels was dramatically reduced with drying at $100^{\circ} \mathrm{C}$; however, it was not significantly affected by drying at $60^{\circ} \mathrm{C}$ (Larrauri et al., 1997). Drying time played an important role in the reduction of antioxidant activity. When the drying time at $60^{\circ} \mathrm{C}$ was compared, our marigold petals were dried 6 times longer than that of Larrauri et al. (1997). Gong et al. (2012) also reported that the antioxidant activities were highly correlated with the content of total phenolics and flavonoids, suggesting that the loss of these compounds during the drying process may reduce the antioxidant activity significantly.

GA and QT content in the tested marigold cultivars is also displayed in Table 2. GA content ranged between 3.93 and $25.77 \mathrm{mg} \mathrm{GA} / \mathrm{g}$ dry marigold petal, and the QT content ranged from 4.64 to $12.61 \mathrm{mg}$ QT/g dry marigold petal. 'Optiva Orange' showed the highest of GA and QT contents. Even though the 'Optiva Orange' and 'Rodeo Gold' cultivars showed the highest total phenolic content, the contribution of GA and QT content in 'Rodeo Gold' was only $31.3 \%$ of total phenolics, as compared to that in 'Optiva Orange' (49.1\%). This implies that the total phenolics of marigold petals may be composed of many different phenolic compounds. Only the 'Optiva Orange' cultivar showed high values of both GA and QT.

Lutein content in the marigold petal extracts ranged from 8.31 to $20.59 \mathrm{mg} \mathrm{LT} / \mathrm{g}$ dry marigold petal (Table 2). 'Optiva Orange' showed the highest lutein content, followed by 'Rodeo Gold' and 'Rodeo Orange', whereas 'Daonoi' showed the lowest lutein content among all analyzed samples. Piccaglia et al. (1998) have reported that marigolds can be considered as a good source of lutein and lutein esters. Although many fruits and vegetables

Table 2. Lutein (LT), gallic acid (GA), and quercetin (QT) content of 11 marigold cultivars.

\begin{tabular}{lccr}
\hline \multicolumn{1}{c}{ Cultivar name } & LT & GA & QT \\
\hline 'Discovery Orange' & $10.65^{\mathrm{d}}$ & $3.93^{\mathrm{i}}$ & $6.15^{\mathrm{f}}$ \\
'Summer Sun Orange' & $10.28^{\mathrm{d}}$ & $18.65^{\mathrm{b}}$ & $11.75^{\mathrm{c}}$ \\
'Columbus Orange' & $10.81^{\mathrm{d}}$ & $11.57^{\mathrm{g}}$ & $7.52^{\mathrm{e}}$ \\
'Rodeo Gold' & $17.07^{\mathrm{b}}$ & $15.12^{\mathrm{e}}$ & $9.60^{\mathrm{d}}$ \\
'Rodeo Orange' & $16.58^{\mathrm{b}}$ & $17.21^{\mathrm{c}}$ & $12.20^{\mathrm{b}}$ \\
'Lunar Orange' & $13.25^{\mathrm{c}}$ & $13.15^{\mathrm{f}}$ & $7.69^{\mathrm{e}}$ \\
'Barbuda Gold' & $10.56^{\mathrm{d}}$ & $18.12^{\mathrm{b}}$ & $9.53^{\mathrm{d}}$ \\
'Jamica Orange' & $10.44^{\mathrm{d}}$ & $7.25^{\mathrm{h}}$ & $4.64^{\mathrm{g}}$ \\
'Optiva Orange' & $20.59^{\mathrm{a}}$ & $25.77^{\mathrm{a}}$ & $12.61^{\mathrm{a}}$ \\
'Sovereign Gold' & $11.22^{\mathrm{d}}$ & $11.85^{\mathrm{g}}$ & $9.56^{\mathrm{d}}$ \\
'Daonoi' & $8.31^{\mathrm{e}}$ & $15.82^{\mathrm{e}}$ & $9.76^{\mathrm{d}}$ \\
\hline
\end{tabular}

LT content expressed as mg of LT/g. GA content expressed as mg of GA/g. QT content expressed as $\mathrm{mg}$ of QT/g. Significantly different at $95 \%$ level of confidence from Duncan's multiple-range test. Means denoted with different letters within the same column were observed to differ significantly $(\mathrm{n}=3)$. contain lutein, the marigold flower is the best commercial source of pure lutein. Khalil et al. (2012) have also studied the lutein and lutein ester extracted from the marigold flower (T. erecta) planted in Germany. They found that the T. erecta type 'Orangeprinz' was the richest source of lutein ester $(14.4 \pm 0.234 \mathrm{mg} / \mathrm{g})$ in comparison with other Tagetes spp. However, our study has demonstrated that the Thai marigold cultivar, 'Optiva Orange', contained much higher lutein content (20.59 mg of LT/g dry marigold petal) than the 'Orangeprinz' cultivar.

Orange marigold cultivars, such as 'Optiva Orange', were reported to possess high lutein content. This observation was in agreement with the conclusions of studies on the Indian marigold, conducted by Bhattacharyya et al. (2010). They reported that the orange marigold cultivar showed the highest antioxidant values in the DPPH and ABTS assays, and also displayed the same trend for lutein ester content as that observed in our study. Conversely, 'Columbus orange', one of the orange cultivars tested did not show high antioxidant activity. We believe that other antioxidant compounds in the marigold extract might have acted synergistically, and affected the antioxidant activity assay (Parejo et al., 2002). Therefore, we propose that high antioxidant activity does not necessarily indicate high lutein content in the extracts.

\subsection{Correlation between assays}

Relationship between TPC, antioxidant assays, LT, and GA and QT content (Table 3) was analyzed. Unlike the result of Gong et al. (2012), our study showed high correlation of LT content with all the antioxidant assays as compared to those of GA and QT content.

Two different results were observed in terms of correlation of GA and QT to antioxidant activity values. In the case of the electron transfer assays, such as the ABTS, FRAP, and DPPH assays, the correlation coefficient was observed to be relatively low. However, the HAT assay (ORAC) showed a significantly higher correlation coefficient value compared to those shown by the ET group. This result coincides with the observations of two following studies. Leopoldini et al. (2004) compared the mechanism of hydrogen atom and electron transfer in phenolic compounds, and concluded gallic acid to be one of the most active systems in the transfer of hydrogen atoms. Supporting evidence was also provided by the research conducted by Rice-Evans et al. (1996), which showed the effect of the chemical structure of flavonoids and phenolic acids on the antioxidant activity.

Table 3. Linear correlation coefficients $(r)$ between total phenolic content (TPC), antioxidant assays, lutein (LT), and gallic acid (GA) and quercetin (QT) contents of 11 marigold cultivars, obtained by Pearson's analysis.

\begin{tabular}{lllllll}
\hline & TPC & ABTS & FRAP & DPPH & ORAC & SRSA \\
\hline LT & $0.641^{* *}$ & $0.528^{*}$ & $0.645^{* *}$ & $0.513^{*}$ & $0.666^{* *}$ & $0.721^{* *}$ \\
GA & $0.359^{*}$ & 0.164 & 0.301 & 0.153 & $0.470^{*}$ & $0.538^{* *}$ \\
QT & $0.397^{*}$ & 0.251 & $0.350^{*}$ & 0.208 & $0.444^{*}$ & $0.555^{* *}$ \\
\hline
\end{tabular}

${ }^{*}$ Correlation is significant at the 0.05 level ( 2 -tailed); ${ }^{* *}$ Correlation is significant at the 0.01 level (2-tailed). 


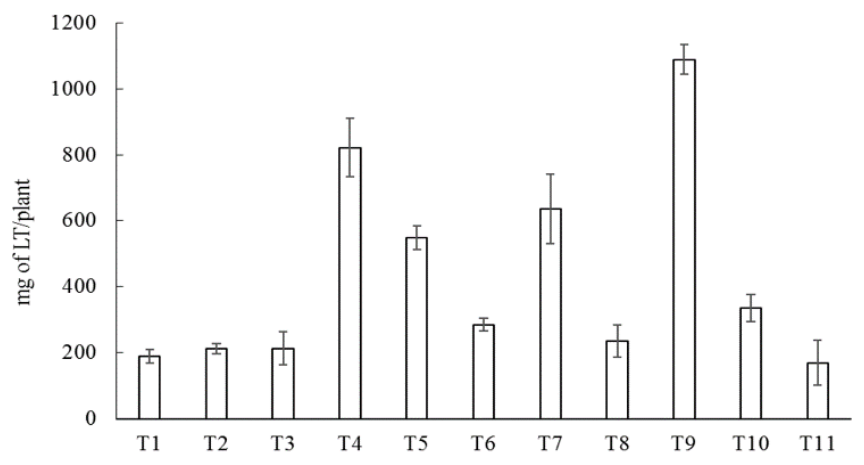

Figure 1. Comparison of lutein yield in 11 marigold cultivars. T1: 'Discovery Orange'; T2: 'Summer Sun Orange’; T3: 'Columbus Orange’; T4: 'Rodeo Gold'; T5: 'Rodeo Orange'; T6: 'Lunar Orange'; T7: 'Barbuda Gold'; T8: 'Jamica Orange'; T9: 'Optiva Orange'; T10: 'Sovereign Gold'; T11: 'Daonoi' $(n=3)$.

\subsection{Lutein yield from different marigold cultivars}

The yield of marigold flower is an important factor to be considered; only the cultivar with high antioxidant activity and high yield can be considered as a good source for commercial use. Lutein yields obtained from different cultivars are shown in Figure 1. The 'Barbuda Gold' cultivar exhibited the highest fresh flower weight and yield, whereas 'Rodeo Gold' showed the highest number of flowers per marigold plant (Manochai et al., 2011). With regards to lutein yield, however, the 'Optiva Orange' cultivar showed the highest yield of $1089 \mathrm{mg}$ per plant, and $17.9 \mathrm{mg}$ per flower head, and also showed five times high lutein yield compared to the 'Daonoi', 'Discovery Orange,' 'Summer Sun Orange', and 'Columbus Orange' cultivars. 'Rodeo Gold' cultivar was the second best type (although, with a significantly lesser yield compared to that in 'Optiva Orange'). In addition, 'Optiva Orange' showed the highest gallic acid and quercetin content, as well as the highest activity values in the ORAC and $\%$ SRSA assays.

\section{Conclusions}

Lutein obtained from marigold petals is of major commercial interest because of its use in functional food and cosmetics, as well as in pharmaceuticals. The production yield from each marigold plant is very important for the large-scale extraction of lutein, in terms of cost efficiency. In this study, 'Optiva Orange' and 'Rodeo Gold' cultivars were determined to be the best candidates for the commercial extraction of lutein, because of their high lutein yield and antioxidant activities.

\section{Acknowledgements}

This work was supported by a grant from Research Year of Inje University in 2012 (20120989).

\section{References}

Al-Duais, M., Müller, L., Böhm, V., \& Jetschke, G. (2009). Antioxidant capacity and total phenolics of Cyphostemma digitatum before and after processing: use of different assays. European Food Research and Technology, 228(5), 813-821. http://dx.doi.org/10.1007/s00217008-0994-8.

Benzie, I. F. F., \& Strain, J. J. (1996). The ferric reducing ability of plasma (FRAP) as a measure of "antioxidant power": the FRAP assay. Analytical Biochemistry, 239(1), 70-76. http://dx.doi.org/10.1006/ abio.1996.0292. PMid:8660627.

Bhattacharyya, S., Datta, S., Mallick, B., Dhar, P., \& Ghosh, S. (2010). Lutein content and in vitro antioxidant activity of different cultivars of Indian marigold flower (Tagetes patula L.) extracts. Journal of Agricultural and Food Chemistry, 58(14), 8259-8264. http://dx.doi. org/10.1021/jf101262e. PMid:20568770.

Ćetković, G. S., Djilas, S. M., Čanadanović-Brunet, J. M., \& Tumbas, V. T. (2004). Antioxidant properties of marigold extracts. Food Research International, 37(7), 643-650. http://dx.doi.org/10.1016/j. foodres.2004.01.010.

Číž, M., Čížová, H., Denev, P., Kratchanova, M., Slavov, A., \& Lojek, A. (2010). Different methods for control and comparison of the antioxidant properties of vegetables. Food Control, 21(4), 518-523. http://dx.doi.org/10.1016/j.foodcont.2009.07.017.

Dávalos, A., Bartolomé, B., \& Gómez-Cordovés, C. (2005). Antioxidant properties of commercial grape juices and vinegars. Food Chemistry, 93(2), 325-330. http://dx.doi.org/10.1016/j.foodchem.2004.09.030.

Fernández-Sevilla, J. M., Acién Fernández, F. G., \& Molina Grima, E. (2010). Biotechnological production of lutein and its applications. Applied Microbiology and Biotechnology, 86(1), 27-40. http://dx.doi. org/10.1007/s00253-009-2420-y. PMid:20091305.

Fukumoto, L. R., \& Mazza, G. (2000). Assessing antioxidant and prooxidant activities of phenolic compounds. Journal of Agricultural and Food Chemistry, 48(8), 3597-3604. http://dx.doi.org/10.1021/ jf000220w. PMid:10956156.

Gong, Y., Liu, X., He, W. H., Xu, H. G., Yuan, F., \& Gao, Y. X. (2012). Investigation into the antioxidant activity and chemical composition of alcoholic extracts from defatted marigold (Tagetes erecta L.) residue. Fitoterapia, 83(3), 481-489. http://dx.doi.org/10.1016/j. fitote.2011.12.013. PMid:22223143.

Heim, K. E., Tagliaferro, A. R., \& Bobilya, D. J. (2002). Flavonoid antioxidants: chemistry, metabolism and structure-activity relationships. The Journal of Nutritional Biochemistry, 13(10), 572-584. http:// dx.doi.org/10.1016/S0955-2863(02)00208-5. PMid:12550068.

Hojnik, M., Škerget, M., \& Knez, Ž. (2008). Extraction of lutein from marigold flower petals-experimental kinetics and modelling. LWTFood Science and Technology, 41(10), 2008-2016. http://dx.doi. org/10.1016/j.lwt.2007.11.017.

Huang, D., Ou, B., \& Prior, R. L. (2005). The chemistry behind antioxidant capacity assays. Journal of Agricultural and Food Chemistry, 53(6), 1841-1856. http://dx.doi.org/10.1021/jf030723c. PMid:15769103.

Kähkönen, M. P., Hopia, A. I., Vuorela, H. J., Rauha, J. P., Pihlaja, K., Kujala, T. S., \& Heinonen, M. (1999). Antioxidant activity of plant extracts containing phenolic compounds. Journal of Agricultural and Food Chemistry, 47(10), 3954-3962. http://dx.doi.org/10.1021/ jf990146l. PMid:10552749.

Kaisoon, O., Siriamornpun, S., Weerapreeyakul, N., \& Meeso, N. (2011). Phenolic compounds and antioxidant activities of edible flowers from Thailand. Journal of Functional Foods, 3(2), 88-99. http:// dx.doi.org/10.1016/j.jff.2011.03.002.

Karadag, A., Ozcelik, B., \& Saner, S. (2009). Review of methods to determine antioxidant capacities. Food Analytical Methods, 2(1), 41-60. http://dx.doi.org/10.1007/s12161-008-9067-7.

Khalil, M., Raila, J., Ali, M., Islam, K. M. S., Schenk, R., Krause, J. P., Schweigert, F. J., \& Rawel, H. (2012). Stability and bioavailability of 
lutein ester supplements from Tagetes flower prepared under food processing conditions. Journal of Functional Foods, 4(3), 602-610. http://dx.doi.org/10.1016/j.jff.2012.03.006.

Kijlstra, A., Tian, Y., Kelly, E. R., \& Berendschot, T. T. J. M. (2012). Lutein: more than just a filter for blue light. Progress in Retinal and Eye Research, 31(4), 303-315. http://dx.doi.org/10.1016/j. preteyeres.2012.03.002. PMid:22465791.

Kumar, N., Bhandari, P., Singh, B., Gupta, A. P., \& Kaul, V. K. (2008). Reversed phase-HPLC for rapid determination of polyphenols in flowers of rose species. Journal of Separation Science, 31(2), 262-267. http://dx.doi.org/10.1002/jssc.200700372. PMid:18172921.

Larrauri, J. A., Rupérez, P., \& Saura-Calixto, F. (1997). Effect of drying temperature on the stability of polyphenols and antioxidant activity of red grape pomace peels. Journal of Agricultural and Food Chemistry, 45(4), 1390-1393. http://dx.doi.org/10.1021/jf960282f.

Leopoldini, M., Marino, T., Russo, N., \& Toscano, M. (2004). Antioxidant properties of phenolic compounds: H-Atom versus electron transfer mechanism. The Journal of Physical Chemistry A, 108(22), 4916-4922. http://dx.doi.org/10.1021/jp037247d.

Li, W., Gao, Y., Zhao, J., \& Wang, Q. (2007). Phenolic, flavonoid, and lutein ester content and antioxidant activity of 11 cultivars of chinese marigold. Journal of Agricultural and Food Chemistry, 55(21), 84788484. http://dx.doi.org/10.1021/jf071696j. PMid:17894452.

Lin, H. Y., \& Chou, C. C. (2004). Antioxidative activities of water-soluble disaccharide chitosan derivatives. Food Research International, 37(9), 883-889. http://dx.doi.org/10.1016/j.foodres.2004.04.007.

Ma, X., Wu, H., Liu, L., Yao, Q., Wang, S., Zhan, R., Xing, S., \& Zhou, Y. (2011). Polyphenolic compounds and antioxidant properties in mango fruits. Scientia Horticulturae, 129(1), 102-107. http://dx.doi. org/10.1016/j.scienta.2011.03.015.

Manochai, B., Sophon, W., Kaewsorn, P., \& Hong, J. H. (2011). Antioxidant activity of commercial marigolds (Tagetes spp.). Thai Journal of Agriculture, 42, 375-378.

Ou, B., Hampsch-Woodill, M., \& Prior, R. L. (2001). Development and validation of an improved oxygen radical absorbance capacity assay using fluorescein as the fluorescent probe. Journal of Agricultural and Food Chemistry, 49(10), 4619-4626. http://dx.doi.org/10.1021/ jf010586o. PMid:11599998.

Parejo, I., Viladomat, F., Bastida, J., Rosas-Romero, A., Flerlage, N., Burillo, J., \& Codina, C. (2002). Comparison between the radical scavenging activity and antioxidant activity of six distilled and nondistilled mediterranean herbs and aromatic plants. Journal of Agricultural and Food Chemistry, 50(23), 6882-6890. http://dx.doi. org/10.1021/jf020540a. PMid:12405792.

Piccaglia, R., Marotti, M., \& Grandi, S. (1998). Lutein and lutein ester content in different types of Tagetes patula and T. erecta. Industrial Crops and Products, 8(1), 45-51. http://dx.doi.org/10.1016/S09266690(97)10005-X.

Rice-Evans, C. A., Miller, N. J., \& Paganga, G. (1996). Structureantioxidant activity relationships of flavonoids and phenolic acids. Free Radical Biology \& Medicine, 20(7), 933-956. http://dx.doi. org/10.1016/0891-5849(95)02227-9. PMid:8743980.

Rivas, J. D. (1989). Reversed-phase high-performance liquid chromatographic separation of lutein and lutein fatty acid esters from marigold flower petal powder. Journal of Chromatography, 464(2), 442-447. PMid:2722992.

Sharma, U. K., Sharma, K., Sharma, N., Sharma, A., Singh, H. P., \& Sinha, A. K. (2008). Microwave-assisted efficient extraction of different parts of Hippophae rhamnoides for the comparative evaluation of antioxidant activity and quantification of its phenolic constituents by reverse-phase high-performance liquid chromatography (RPHPLC). Journal of Agricultural and Food Chemistry, 56(2), 374-379. http://dx.doi.org/10.1021/jf072510j. PMid:18163559.

Sokolova, E. V., Barabanova, A. O., Bogdanovich, R. N., Khomenko, V. A., Solov'eva, T. F., \& Yermak, I. M. (2011). In vitro antioxidant properties of red algal polysaccharides. Biomedicine \& Preventive Nutrition, 1(3), 161-167. http://dx.doi.org/10.1016/j.bionut.2011.06.011.

Vasudevan, P., Kashyap, S., \& Sharma, S. (1997). Tagetes: a multipurpose plant. Bioresource Technology, 62(1-2), 29-35. http://dx.doi.org/10.1016/ S0960-8524(97)00101-6.

Wichtl, M., \& Bisset, N. G. (1994). Herbal drugs and phytopharmaceuticals. Stuttgart: Medpharm Scientific. 